Poznańskie Studia Teologiczne 30(2016), s. 369-383.

doi: $10.14746 /$ pst.2016.30.18

Piotr Liszka ${ }^{1}$

Papieski Wydział Teologiczny we Wrocławiu

\title{
Trynitarny aspekt creatio continua
}

Zagadnienie zwane creatio continua powinno być opracowane w kontekście trynitologii. Aspekt temporalny ma tu znaczenie drugorzędne, aczkolwiek istnienie świata - rozpiętego w czasie - stanowi punkt wyjścia klasycznych refleksji z zakresu kreatologii. Specyfiką tego artykułu nie jest jakiś fragment refleksji dotyczącej stworzenia świata, lecz przede wszystkim aspekt trynitarny. Aspekt temporalny będzie w nim ograniczony. Pominięta zostanie kwestia rozumienia czasu kosmicznego. Uwypuklone będzie znaczenie kilku momentów czasu, w których dokonały się najważniejsze wydarzenia zbawcze o stwórczym charakterze. Akt stwórczy dotyczy nie tylko stworzenia materii, lecz również bytów duchowych, a także zbawczych zmian dokonywanych przez Boga w duszach ludzkich.

Akt stwórczy jest czynem Boga dokonującym się w bezczasowym, bezprzestrzennym, wiecznym życiu Trójcy Świętej. Na zewnątrz Boga jawi się w postaci zaistnienia świata, pojawienia się człowieka, podtrzymywania świata $\mathrm{w}$ istnieniu i wzmacnianiu ludzi łaską aż do pełni świętości w doczesności i pełni chwały nieba. Kluczowe wydarzenia zbawcze to wcielenie Syna Bożego oraz śmierć i zmartwychwstanie Jezusa Chrystusa. Natomiast w życiu ludzi kluczowymi wydarzeniami są sakramenty, poprzez które pojawia się w osobie ludzkiej stworzona energia boska, czyli łaska. W tym kontekście każdy traktat teologiczny, każde zagadnienie jest w jakimś aspekcie częścią kreatologii. Kreatologia z kolei, jak i wszystkie inne traktaty, powinna być ujmowana w świetle trynitologii. Po paruzji nie będzie już stwórczego wzrastania ludzi w wymiarze czasowym, lecz uczestniczenie $\mathrm{w}$ wewnątrztrynitarnym akcie stwórczym, uczestniczenie we wnętrzu życia Boga Trójjedynego.

Creatio continua to pogląd alternatywny wobec poglądu mówiącego o jednym jedynym działaniu stwórczym na początku świata. W sensie ścisłym polega na ciagłym stwarzaniu kosmosu, ale dotyczy też nieciagłego, punktowego stwarzania nowych bytów. Wśród nich podkreślane jest stwarzanie w określonych

\footnotetext{
${ }^{1}$ Piotr Liszka CMF (Misjonarze Klaretyni), o. prof. dr hab., ur. 19.01.1951 w Chorzowie. Profesor zwyczajny papieskiego Wydziału Teologicznego we Wrocławiu. Kierownik katedry eklezjologii i sakramentologii. Ostatnia publikacja: Dusza (substancja duchowa człowieka).
} 
punktach czasu nowych substancji duchowych (dusz ludzkich), a następnie stwarzanie nowego życia duchowego (łaski uświęcającej). Stwarzanie w czasie jest rozwinięciem aktu stwórczego i trwa od punktu alfalnego do punktu omega - do paruzji. Ostateczne zwieńczenie omawianego aktu objawi się w powszechnym zmartwychwstaniu i przemianie kosmosu.

Zwrócenie uwagi na aspekt trynitarny oznacza, że refleksja koncentruje się nie na skutkach aktu stwórczego, lecz na jego Podmiocie. W teologii chrześcijańskiej nie wystarczy powiedzieć, że stwórcą jest Bóg, trzeba powiedzieć, że jest nim Bóg w Trójcy Jedyny. Rdzeniem teologii jest refleksja nad relacjami. Rdzeniem niniejszego artykułu jest refleksja nad relacją Trójcy Świętej do czasu w jego całości wyrażająca się w stwórczym działaniu zbawczym dokonywanym w najważniejszych punktach czasu.

\section{Istota creatio continua: ciągłość procesu stwórczego}

W odniesieniu do świata materialnego kwestia relacji aktu stwórczego do czasu ma rangę opinii teologicznej, nie jest dogmatem. Można przyjąć, że świat został powołany do istnienia jednorazowo, wraz z odpowiednim wyposażeniem umożliwiającym bytowanie w czasie oraz jego rozwój. Można też założyć, że stwórcze działanie Boga dokonuje się w każdym momencie albo przynajmniej w wielu punktach czasu. Problem dwoistości poglądów wynika z misteryjności relacji między bezczasową wiecznością a czasem płynącym w doczesności. Od strony Boga relacja z całością czasu i relacja z początkiem czasu jest identyczna. Od strony świata problem ten w teologii może być ubogacany przez nowe teorie fizykalne dotyczące czasu ściśle powiązanego z przestrzenią i materią. Wśród nich wyróżniają się teoria względności i teoria kwantów ${ }^{2}$. Stwórcze działanie Boga jest czynem dokonującym się bezczasowo we wnętrzu Boga, ale może być opisywane w teologii odgórnie i oddolnie.

Kolejnym zadaniem teologii jest opisywanie działania Boga w świecie już istniejącym, opisywanie relacji między działaniem Boga w wieczności a działaniem Boga w czasie oraz relacji między działaniem Boga w świecie a czasoprzestrzennym środowiskiem, które stanowi pośredni etap w opisywaniu relacji między Bogiem samym w sobie a czasoprzestrzenią. Wśród tych zagadnień pojawia się pytanie o relację między działaniem Boga sprawiającym początek świata a działaniem Boga, które objawia się jako nieustanna ingerencja w istniejący już

\footnotetext{
${ }^{2}$ Nadzieje na lepsze zrozumienie początków kosmosu daje empiryczne zarejestrowanie fal grawitacyjnych. Od wieków wiadomo było, że istnieje grawitacja i że obiekty kosmiczne się poruszają. Jednak dopiero Albert Einstein zespolił te spostrzeżenia w formie teorii względności. Skoro obiekty kosmiczne poruszają się, to ich oddziaływanie grawitacyjne w poszczególnych punktach kosmosu się zmienia. Zmienność to falowanie natężenia grawitacji. Dopiero sto lat później (pod koniec roku 2015) udało się zarejestrować fale grawitacyjne.
} 
i rozwijający się świat. Od strony Boga jest to jeden i ten sam akt stwórczy. Od strony świata (z punktu widzenia żyjącego w nim teologa) można mówić o różnych stwórczych działaniach Boga. Inne jest działanie Boga podtrzymujące świat $\mathrm{w}$ istnieniu, inne sprawia, że pojawiają się kolejne dusze ludzkie, inne powoduje pojawianie się łaski w ludziach, którzy ją utracili. Tak rozumiana creatio continua nie polega na ingerencji Boga w naturalny rozwój świata materialnego, lecz dotyczy stwarzania bytów duchowych i stwarzania w nich nowej jakości, nowego poziomu bytowania duchowego. W publikacjach teologicznych często pojawia się polemika z zarzutami stawianymi przez materialistów. Nie stawiają oni zarzutów dotyczących stwarzania nowych bytów duchowych, gdyż w ogóle nie uznają ich istnienia. Niniejszy artykuł nie jest poświęcony kwestii możliwości interpretowania pierwszego rozdziału Księgi Rodzaju jako kilka odrębnych działań stwórczych, dokonywanych w dziejach świata materialnego. Ingerencje Boga w świat dotyczą tu jedynie pojawienia się w nim bytów niematerialnych - indywidualnych substancji duchowych (dusz ludzkich) powiązanych z konkretnymi indywidualnymi substancjami materialnymi (ciałami ludzkimi).

W kontekście Pierwszego Przymierza refleksja nad creatio continua dotyczy tylko świata materialnego. W Nowym Testamencie rozważania te zostają przeniesione na świat duchowy. Nowotestamentalna refleksja nad creatio continua jest $\mathrm{z}$ istoty swej trynitarna. Starotestamentalną refleksję nad creatio continua (ograniczoną do świata materialnego) można reinterpretować w świetle trynitologii. Bardziej oczywista, naturalna i spójna jest refleksja trynitarna dotycząca stworzenia i rozwoju duszy ludzkiej ${ }^{3}$. W odniesieniu do człowieka kwestia stwarzania łaski uświęcającej jest stawiana tylko w myśleniu integralnym, nie ma jej w myśleniu oddzielającym i w myśleniu mieszającym. Model oddzielający nie uznaje działania łaski w człowieku. Tym samym nie uznaje możliwości stworzenia w życiu doczesnym człowieka nowej sytuacji duchowej. Model mieszający zakłada, że łaska jest niezbywalnym elementem natury ludzkiej. W takiej sytuacji nie ma sensu mówienie o stwarzaniu jej u człowieka, który ją utracił. Model integralny przyjmuje możliwość utraty łaski oraz możliwość jej odzyskania, a także istnienie procesu wzrastania w łasce, czyli creatio continua personalnego, dokonującego się w naturze ludzkiej. Człowiek może znajdować się w sytuacji regresu, po którym może nastąpić dalszy ciagg wzrastania w łasce. Zagadnieniem tym zajmuje się charytologia.

Dotychczas refleksja teologów chrześcijańskich nad ciagłym działaniem stwórczym nie jest podejmowana w świetle trynitarnym. Na ogół jest mowa tylko o Absolucie albo o jednoosobowym Bogu. W tej sytuacji bardziej inspirujące są niektóre próby podejmowane przez niechrześcijan, którzy nie mają światła

\footnotetext{
${ }^{3}$ Refleksja nad relacją natury ludzkiej (duszy i ciała) do łaski powinna być czyniona z zastosowaniem narzędzia intelektualnego zwanego „trzy modele myślenia”. Powinni znać je wszyscy ludzie zajmujący się jakakolwiek nauką. W publikacjach popularnonaukowych trzeba za każdym razem wszystko wyjaśniać od podstaw.
} 
Nowego Testamentu i dokonują karkołomnych wysiłków, aby dać przynajmniej trochę lepsze wyjaśnienie tajemnicy stworzenia świata.

Żydowski filozof dialogu, Lévinas stwierdza, że Stwórca nie musi ciągle podtrzymywać bytu w istnieniu. Świat znajduje się na zewnątrz Boga i jest pozostawiony samemu sobie ${ }^{4}$. Jest odseparowany od Boga, oddzielony, zupełnie inny. Stworzyć to pozwolić istnieć czemuś poza Stwórca, oddzielnie, pozwolić być oddzielonym, niczym niezwiązanym, wolnym. Jeżeli nie ma ciągłej relacji Boga ze światem, to różne porządki bytowe: wegetatywny, zwierzęcy i ludzki, są wynikiem ewolucji dokonującej się całkowicie poza Bogiem albo są stwarzane zupełnie odrębnymi aktami. Lévinas wyklucza możliwość ciagłej relacji świata do Boga, która przyjmuje ewolucję, ale uznaje Boga za jej Pierwsze Źródło.

Pogląd ten radykalnie ujęła kreatologia islamska, rozciągając stworzenie świata między początkiem i końcem, ale nie w sposób ciągły, lecz punktowy. W każdym punkcie Bóg stwarza świat od nowa. Nie ma mowy o ciagłym działaniu Boga w czasie. Bóg w ogóle nie działa w czasie, nie wchodzi w czas, lecz w każdym punkcie stwarza go na nowo. Nie ma ciągłości horyzontalnej, jest tylko wertykalna relacja świata do Boga, w każdym punkcie nowa. Tożsamość świata zapewniona jest w tożsamości Stworzyciela, wynika tylko z woli Bożej. W takim ujęciu nie ma przyczynowości. Człowiek na nic nie może wpłynąć. Przyszłość zależy tylko i wyłącznie od absolutnie wolnej woli Boga5 ${ }^{5}$ Zauważyć tu można podobieństwo do kwantowej teorii czasu. W islamie byty stworzone są niczym, są całkowicie zależne od niczym nieskrępowanej woli Bożej6.

Teologia katolicka kładzie nacisk na związek odwiecznego działania Boga z autonomicznym rozwojem świata. Jeden i ten sam akt stwórczy rozszczepia się na całą ewolucję stworzenia. Nowoczesne ujęcie creatio continua dostrzega, że moc Boża rozwijająca świat, zawarta jest nie tylko w wydarzeniu początkowym, lecz również w wydarzeniu końcowym, nie tylko w punkcie alfa, lecz również w punkcie omega, w sensie ontycznym: w Chrystusie, który jest Alfą i Omegą, który z dwóch punktów krańcowych ogarnia całość świata. Dziś, za Piotrem Teilhardem de Chardin podkreślany jest nie tylko rozwój świata z punktu alfa, lecz również omegalizacja wszelkich stworzeń, przyciaganie świata przez Chrystusa. Zwraca na to uwagę lubelski teolog Czesław Stanisław Bartnik, dla którego stworzenie to nie „misterium początku”, lecz przede wszystkim „misterium końca”. W tym ujęciu kreatologia utożsamia się z eschatologią bardziej niż z protologią. Pełnia stworzenia zaktualizuje się dopiero u kresu czasu?

\footnotetext{
${ }^{4}$ Por. M.L. Costa, Emmanuel Lévinas y Hayyim de Volozhyn: praximidad e inspiración, „Anámnesis” 1(1998), s. 134.

${ }^{5}$ Por. tamże, s. 135.

${ }^{6}$ Por. A. Benz, Skqd się pojawia coś nowego w Universum?, „Communio”, Stworzenie czy natura? 2(2002), s. 4.

${ }^{7}$ Por. C.S. Bartnik, Dogmatyka katolicka, t. 1, Lublin 2000, s. 251.
} 
Tego rodzaju pogląd jest na wskroś chrześcijański, wynika ze specyfiki działania Syna Bożego i Ducha Świętego. Protologia w kontekście trynitologii podkreśla kluczowe znaczenie Boga Ojca, który jest źródłem absolutnym, a jego specyficzną cechą personalną jest dawanie. Źródłem świata jest Bóg Trójjedyny, a w Trójcy źródłem jest Ojciec (Arche). Eschatologia podkreśla rolę Syna Bożego, którego specyficzną cechą jest przyjmowanie. W biblijnym schemacie logicznym Ojciec najpierw daje, a następnie otrzymuje, Syn najpierw otrzymuje, a następnie daje siebie Ojcu. Przyjmowanie, które jest specyficzną cechą Syna Bożego, objawia się przede wszystkim w wydarzeniu wcielenia, czyli przyjęcia przez Niego natury ludzkiej, następnie w tworzeniu Kościoła poprzez przyciagganie ludzi do siebie i gromadzenie ich wokół siebie, a ostatecznie objawi się w paruzji. Chrystus stwarza nową ludzkość, z bezładnej masy ludzkiej buduje Zgromadzenie Święte. Chrystus-Omega przyciaga wszystkich do siebie jako Bóg i jako człowiek - mocą otrzymaną na Krzyżu i objawioną w zmartwychwstaniu.

Działanie ciągle objawiającego się aktu stwórczego harmonijnie ukazał Pseudo-Dionizy Areopagita, tworząc wielki system jednoczący wszelkie byty stworzone między sobą i z Bogiem. W tym ujęciu Bóg jest początkiem i końcem wszystkiego. System Dionizego nie jest statyczny, lecz dynamiczny. Symbolizuje proces, w którym dokonuje się nieustanny rozwój świata, a koniec nie oznacza zniknięcia, lecz jego spełnienie. Zachowana jest odrębność Boga od świata a jednocześnie ich relacja. Bóg stworzył najpierw wzorce, fundamentalne zasady, odpowiedniki „mądrości stworzonej” z Księgi Mądrości. Według Pseudo-Dionizego Areopagity akt stwórczy zawiera szereg obrazów i paradygmatów, które są wzorcami bytowania i sposobu działania świata. Władimir Łosski uważał, że akt stwórczy promieniuje na zewnątrz Boga i jaśnieje w świecie w postaci pierwowzorów (pronoiai). W zamyśle Bożym są idee, a w świecie byty realne. Stworzone pierwowzory to tylko byty myślne, obrazy, plany, które są odblaskiem wnętrza Boga, jaśniejącym w czasoprzestrzeni i wyznaczającym miejsce i kształt bytów realnych. Bezczasowe światło Bożego zamysłu zostaje rozszczepione w wielość planów, schematów, szkiców struktur rzeczy, które zaistnieją na ich podstawie ${ }^{8}$.

Ciagłe stwarzanie pierwowzorów nie wyjaśnia jeszcze tego, na czym polega relacja aktu stwórczego z realnym światem, rozwijającym się w realnym czasie. System Dionizego stara się tłumaczyć relację Boga ze światem, posługując się zestawem bytów pośrednich, ale tej relacji nie wyjaśnia. Cenne jest w nim podkreślanie trynitarności aktu stwórczego i odpowiednio - trynitarności bytów stworzonych. Według tego ujęcia, creatio continua to rozszczepienie odwiecznej

${ }^{8}$ Por. M. Korczyński, Teologia kosmiczna w pismach Pseudo Dionizego Areopagity, Radom 1997, s. 32; por. W. Łosski, Teologia mistyczna Kościoła wschodniego, thum. M. Sczaniecka, Warszawa 1989, s. 86 . 
troski Boga Trójedynego o świat zawartej w Bożym zamyśle, na rzeczywistość wyznaczoną przez czas i przestrzeń. Odwieczny plan Opatrzności jest trynitarny i taki też jest świat i jego dzieje. Bóg ma w sobie ,przyczynową godność (dignitas causalitatis), zdolność do działania w świecie czasowym, którą przyznaje w całym swoim dziele wszystkim stworzeniom".

Trynitarne rozumienie aktu stwórczego daje możliwość mówienia o działaniu Opatrzności w każdym momencie dziejów świata. W działaniu Bożym creatio continua to nie tylko trwanie aktu stwórczego od początku do końca, lecz również conservatio mundi, czyli podtrzymywanie świata i utrzymywanie świata w należytym porządku. Dokonuje się to poprzez concursus divinus, czyli współdziałanie Boga $\mathrm{z}$ wolnym człowiekiem $\mathrm{i}$ innymi przyczynami wtórnymi ${ }^{10}$. We współpracy z Bogiem człowiek angażuje nie tylko swoją wolę i uczucia, lecz przede wszystkim intelekt. W ten sposób dokonuje się interpretatio providentialis, czyli interpretowanie przez oświeconego łaską człowieka tego, co się dzieje w świecie i co się dzieje ze światem. Człowiek współpracujący z Opatrznością umieszcza wolę, uczucia oraz intelekt w punkcie Omega i w ten sposób ustawiony jest $\mathrm{w}$ stronę sensów pozytywnych ${ }^{11}$. Bartnik przypomina, że

według wizji dynamicznej jeden i ten sam akt stwórczy trwa ciagle, nic został „zakończony", a nawet ze swej strony jakby narasta, przyśpiesza się (por. KDK 5), uintensywnia i rozjaśnia (creatio continua). Stworzenie jest to akt całościowy i tylko w tym sensie jednorazowy, choć poszczególne byty powstają i gina, to jednak w ramach tego samego aktu stwórczego ${ }^{12}$.

We wszystkich stworzeniach jest zawarty ślad Boga (imago Dei), czyli ślad Boga Trójjedynego (imago Trinitatis). Zawsze jest w nich podstawowa więź Boga ze światem, bez której świat by nie istniał. Warto jednak zauważyć, że wraz z rozwojem bytów odpowiednio zmienia się w nich ślad Boga. Zadaniem teologa jest zastanawianie się nad tym, jak ta więź wygląda i jak się może zmieniać. Teologia chrześcijańska może o tym mówić dzięki odniesieniu kreatologii do trynitologii. Zastanawiał się nad tym biochemik Arthur R. Peacocke, stwierdzając, że: „Bóg jest immanentny w świecie, który jeszcze stwarza. Bóg jest wszędzie i zawsze w procesach i wydarzeniach naturalnego świata"13. Nie potrafił jednak nic powiedzieć, w jaki sposób odwieczna procesualność wewnątrz Boga odzwierciedla się w rozwoju bytów stworzonych. Poza chrześcijaństwem więź Boga ze światem może być tylko zasygnalizowana. Wyjaśnienie jest możliwe wyłącznie w ramach teologii chrześcijańskiej.

${ }^{9}$ M. Cristiani, „Aeterni pia providentia Regis”-Opatrzność a rozumienie świata: Pomiędzy filozofiq a chrześcijaństwem, „Communio” 6(2002), s. 14.

${ }^{10}$ Zob. C.S. Bartnik, Dogmatyka..., s. 140.

${ }^{11}$ Zob. tamże, s. 141.

${ }^{12}$ Tamże, s. 290.

${ }^{13}$ A.R. Peacocke, Creation and the World of Science, Oxford 1979, s. 204. 
Trynitarny jest ślad Boga, trynitarne jest działanie bytów stworzonych i taką strukturę ma ta współpraca bytów stworzonych z opatrznością Bożą ${ }^{14}$. Dotyczy to nie tylko obiektywnej rzeczywistości, lecz jej słownego wyrażenia w języku ludzkim. Rzeczywistość powinna być opisana adekwatnie, a to jest możliwe tylko w świetle Nowego Testamentu. Bartnik zwraca uwagę na to, że „Słowo i zdarzenie stanowią niezwykłą diadę komunikacyjną. Są to rzeczywistości zespolone ze sobą. [...] Obie te rzeczywistości dopełniają się wzajemnie, wyjaśniają i tworzą podstawowy proces teofanijny"15. Objawienie przedchrześcijańskie, w silnie wiązało Boga ze światem poprzez słowa. Dokonało się w nim zjednoczenie mowy Jahwe z mową ludzką ${ }^{16}$. Pełnia zjednoczenia nastapiła we wcieleniu. Przyjęcie natury ludzkiej przez Logos było wydarzeniem przełomowym w działaniu Boga zwanym creatio continua i pozwoliło o nim mówić w nowy sposób, istotnie bardziej adekwatny.

\section{Trynitarny Podmiot creatio continua}

Podmiotem ciągłego stwarzania jest Bóg Trójjedyny, a zwłaszcza druga Osoba Trójcy - Syn Boży. Tak jest od początku świata, ale w realny sposób od wcielenia, które zostało dopełnione wniebowstąpieniem. Wstąpienie Jezusa do Ojca nie było odejściem. Wręcz odwrotnie, początkiem nowego sposobu przebywania Syna Bożego w świecie, początkiem nowego etapu stwarzania świata, początkiem czasu łaski.

\subsection{Bóg podmiotem ciąglego stwarzania}

Sposób rozumienia aktu stwórczego zależny jest od sposobu rozumienia Boga. U ludów zbieracko-łowieckich Bóg to mało sprecyzowana Istota Najwyższa, która albo stanowi projekcję osoby ludzkiej, albo jest niedostrzegalną przez człowieka niebiańską mocą. Boska moc objawiła się w stworzeniu świata i człowieka, objawia się też w ciaggym podtrzymywaniu w istnieniu ${ }^{17}$. Filozofia islamska akcentuje absolutną wolność Boga, mówi nawet o absolutnej dowolności. Szkoła aszarytów podkreśla, że Bóg zapewnia chaotycznie poruszającym się cząsteczkom świata spójność. Bez Boga świat by się rozpadł i niemożliwe byłyby jego dzieje. Bóg dokonuje złożeń cząstek i ciaggle te złożenia zmienia. Odpowiednio, jeden jedyny akt stwórczy rozszczepia się na nieskończoną liczbę chwil i jest gwarancją ich spójności ${ }^{18}$. Monoteizm wiary żydowskiej i chrześcijańskiej filo-

\footnotetext{
${ }^{14}$ Por. G. Greshake, Trójjedyny Bóg. Teologia trynitarna, thum. J. Fyrawa, Wrocław 2009, s. 215.

${ }^{15}$ C.S. Bartnik, Dogmatyka katolicka..., s. 59.

${ }^{16}$ Por. tamże, s. 60.

${ }^{17}$ Por. H. Zimoń, Istota najwyższa, w: Encyklopedia katolicka, t. 7, Lublin 1997, kol. 540.

${ }^{18}$ Z. Kuksiewicz, Zarys filozofii średniowiecznej. Filozofia bizantyjska, krajów zakaukaskich, stowiańska, arabska i żydowska, Warszawa $1982^{2}$, s. 593.
} 
zoficznie wyraził św. Tomasz z Akwinu, określając bytową przepaść Boga od stworzeń za pomocą terminu transcendencja. W stworzeniach Bóg objawia nie tylko swoje istnienie, lecz także swoją naturę ${ }^{19}$.

Zdecydowane odejście od ujęcia fillozoficznego do teologicznego możliwe jest tylko w monoteizmie chrześcijańskim, który głosi, że trzy Osoby Boskie to jedna jedyna substancja boska. W jednej substancji każda z Osób ma swój własny, personalny kształt otwierania się na pozostałe dwie Osoby. Otwartość ta jest wyraźnie ukierunkowana. Każda z Osób jest inaczej ukierunkowana ku pozostałym dwóm Osobom, a tym samym jest inaczej ukierunkowana ku światu w jednym wspólnym akcie stwórczym, który jest misteryjnie zawarty w zamyśle Bo$\dot{z ̇ y m}^{20}$. W samym centrum Boskiego creatio continua i w samym centrum dziejów świata znajduje się Chrystus-Jezus, Bóg-człowiek. Wraz z Bogiem Ojcem i Duchem Świętym inicjuje On wszechświat i podtrzymuje go ${ }^{21}$. Syn Boży jest źródłem i celem, jest personalnym dopełnieniem wszelkiego stworzenia, „aby wszystko na nowo zjednoczyć w Chrystusie [...] to, co w niebiosach, i to, co na ziemi" (Ef 1,9-10) 22. Chrystus jednoczy początek z celem ostatecznym, który stanowi centrum Opatrzności ${ }^{23}$. Katechizm Kościoła katolickiego określa trynitarny charakter creatio continua dość zwięźle, mówiąc, że: „Bóg, który stworzył wszechświat, podtrzymuje go w istnieniu przez swoje Słowo, Syna, który «podtrzymuje wszystko słowem swej potęgi» (Hbr 1,3), i przez Ducha Stwórcę, który daje życie" (KKK 320). W każdym razie wyraźnie jest mowa o tym, że podmiotem creatio continua jest Bóg Trójjedyny. Kwestia jednorazowości czy ciagłości aktu stwórczego jest wtórna wobec podstawowej kwestii możności i faktu stworzenia świata. Najpełniej wyjaśnia te wszystkie zagadnienia trynitarza teologia chrześcijańska, stwierdzając, że podmiotem aktu stwórczego i ciąłej działalności w świecie jest Bóg Trójjedyny ${ }^{24}$.

Filozofia potrafi tylko zauważyć istnienie Pierwszej Przyczyny świata. Nie potrafi jednak udowodnić, czy świat miał początek. Akt stwórczy wykracza poza możliwości wszelkiej filozofii, jest natomiast własnym przedmiotem refleksji teologicznej, przede wszystkim refleksji chrześcijańskiej². Poza chrześcijaństwem

${ }^{19}$ Por. J. Tupikowski, Relacje między Bogiem a światem w ujęciu św. Tomasza z Akwinu u A.N. Whiteheada, Lublin 1999, maszynopis, s. 172.

${ }^{20}$ Por. M. Korczyński, Teologia kosmiczna.., s. 34. Za: W. Stróżewski, Problem panteizmu w De Divinis Nominibus Pseudo Dionizego Areopagity, ,Roczniki Filozoficzne” 5(1955-57), z. 3, s. 39-59.

${ }^{21}$ Por. C.S. Bartnik, Dogmatyka..., s. 74.

${ }^{22}$ Por. C. Gunton, Daleki odblysk Evangelium. Zbawienie we Władcy Pierścieni Tolkiena, w: Tolkien. Księga pamiatkowa. Studia o spuściźnie literackiej, Poznań 2003, s. 131.

${ }^{23}$ Por. O. Boulnois, Nasza koncepcja Boga i Opatrzności, „Communio” 6(2002), s. 92.

${ }^{24}$ Por. S. Zamboni, Luce dell'essere, Dio della tenebra, Ermeneutica della luce nel «Corpus areopagiticum», "Ricerche Teologiche" 10(1999), s. 135.

${ }^{25}$ Por. D.M. Turoldo, Misterium czasu, Kraków 2000, s. 20. 
refleksja nad creatio continua może dotyczyć tylko samej relacji Boga ze światem stworzonym: albo dzieło i Twórca są od siebie radykalnie odrębne, albo się radykalnie mieszają. Chrześcijaństwo pozwala mówić o trynitarnym splocie bezczasowego życia Trójcy z ciagłym aktem stwórczym, czyli związanym z upływającym czasem.

Próby wyjaśnienia sposobu stwarzania świata w wielkich religiach niechrześcijańskich prowadzą często do panteizmu. O panteizmie nie świadczy pojawienie się niematerialnego wzorca dla bytów materialnych, lecz sposób zaistnienia tego wzorca: albo jest on stworzony z niczego, albo wyłania się poprzez emanacje. Nie jest możliwe połączenie panteizmu z systemem niepanteistycznym. Panteizm albo jest, albo go nie ma, nie ma czegoś w połowie drogi. Można natomiast tworzyć jeden system panteistyczny $\mathrm{z}$ dwóch typów panteizmów. Przykładem jest Ibn Arabi, który „usiłuje w swojej koncepcji Boga i świata połączyć orientalne, panteistyczne koncepcje natury oraz zjawiskowość świata z kategorializacją arytotelesowską"26. Panteizm spirytualistyczny Dalekiego Wschodu połączył on z panteizmem materialistycznym Arystotelesa.

W ujęciu panteistycznym świat albo jest sposobem bytowania Boga, albo jest złudzeniem, jest odbiciem bytu absolutnego w niebycie. W ujęciu kreacjonistycznym, cały świat, od powstania do końca jego dziejów, znajduje się w określonej relacji wobec Stworzyciela. Bóg jest Panem czasu, panuje nad początkiem czasu i nad jego najkrótszym momentem oraz nad całością wszechczasów. Bóg jest podmiotem aktu stwórczego, jest transcendentny wobec stworzonego przez siebie świata i niezależny od niego ${ }^{27}$. Pełnia refleksji nad tymi zagadnieniami jest możliwa tylko wtedy, gdy podmiotem aktu stwórczego i podmiotem działania, zwanego creatio continua, jest Trójca Święta.

\subsection{Trójca Święta podmiotem creatio continua}

Zagadnienie creatio continua jest częścią kreatologii. Niestety, poświęcone tym zagadnieniom podręczniki zajmują się przede wszystkim światem stworzonym, a nie działaniem Boga Stworzyciela. Zupełnie pomijana jest w nich refleksja nad stworzeniem świata przez Trójcę Świętą. Teologia jest jedyną dyscypliną uprawnioną i zdolną do refleksji nad trynitarnym kształtem aktu stwórczego.

Źródłem, realizatorem i spełnieniem świata jest Bóg Trójjedyny. W misterium ciagłego stwarzania czyni wszystkie byty stworzone coraz bardziej podobnymi do siebie, personalizuje, wchłania w swoje międzyosobowe życie, w sieć personalnych relacji Osób Bożych. Vestigium trinitatis to nie tylko ślad, ale sam Bóg stwarzający i prowadzący do pełni, popychający do rozwoju i przyciagający wszystko do swego wnętrza ${ }^{28}$. Wszczepienie bytów stworzonych w Boga to nie

\footnotetext{
${ }^{26}$ Tamże, s. 592.

${ }^{27}$ Por. P. Liszka, Wpływ nauki o czasie na refleksję teologicznq, Warszawa 1992, s. 119.

${ }^{28}$ Por. C.S. Bartnik, Dogmatyka..., s. 256.
} 
jakieś bezkształtne włożenie w boską substancję, lecz wszczepienie w odwieczne życie Osób Bożych. W ostatecznym, pełnym communio, relacje bytów stworzonych z poszczególnymi Osobami Bożymi tworzą jedną sieć, w której zespala się wertykalność z horyzontalnością na płaszczyźnie bytów stworzonych i z horyzontalnością na płaszczyźnie wewnątrztrynitarnej ${ }^{29}$.

Model sieci relacji zarysował - wymieniany już - Pseudo-Dionizy Areopagita. Wszystkie relacje w jego systemie mają strukturę trynitarną, oznaczają ruch między bytami, który ma wymiar pionowy, od bytów najwyższych do najniższych, ale też wymiar poprzeczny, odpowiadający analogicznie ruchowi trynitarnemu w substancji Boga. W sumie relacja Boga $\mathrm{z}$ bytami stworzonymi ma kształt spiralny, symbolizujący boską energię, kierującą byty stworzone ku trynitarnej energii niestworzonej, ku wnętrzu życia Boga ${ }^{30}$. W ten sposób dokonuje się trynitarna creatio continua, która swoje zwieńczenie znajduje w bytach duchowych - personalnych, jednostkowych i społecznych.

Trynitarna creatio continua dokonuje się w konkretnych ludziach poprzez narastanie eklezjalnej perychorezy, czyli wzajemnego działania duchowych relacji międzyludkich i relacji wspólnot chrześcijańskich z Bogiem. Źródłem jest perychoreza trynitarna, z której wynika perychoreza chrystologiczna, antropologiczna i eklezjologiczna. Rozwój duchowy dokonuje się poprzez stwarzanie nowego człowieka w łasce i przez współpracę człowieka z łaską. Celem jest ostateczne spełnienie aktu stwórczego w społeczności świętych w niebie. Na Ziemi relacja człowieka $z$ Bogiem nie jest ustalona raz na zawsze i niezmienna. Rozwój świętości w jakiś sposób jest zakodowany, ale też wynika z ciagłego działania Boga w historii, z ciąłłego obdarzania człowieka łaską. W ten sposób dokonująca się we wnętrzu Boga perychoreza trynitarna ogarnia relację Boga do świata i działanie Boga $\mathrm{w}$ jego wnętrzu ${ }^{31}$. Wewnątrz Boga dokonuje się źródłowy trialog trzech Osób Bożych. W wymiarze wertykalnym perychoreza najmocniej dokonuje się w dialogu natury boskiej z naturą ludzką w Osobie Chrystusa. Wewnątrz świata dokonuje się zbawczy multidialog prowadzący do coraz większej współpracy z Bogiem Stworzycielem. Całość zmierza do communio bosko-ludzkiego, do sytuacji ostatecznej, w której „Bóg będzie wszystkim we wszystkich rzeczach" (1 Kor 5,28) ${ }^{32}$.

Personalne creatio continua polega na jednoczesnym przemienianiu bytów w ich wnętrzu oraz ich relacji do innych. Dokonuje się w jednostkach i szerszych

${ }^{29}$ Por. C.S. Bartnik, Dogmatyka..., s. 357.

${ }^{30}$ Por. P. Nawara, Ksztattowanie się koncepcji przebóstwienia ( $\left.\theta \varepsilon \omega \sigma \iota \varsigma\right)$ w myśli teologiczno-filozoficznej wczesnego chrześcijaństwa, w: Studia z filozoficznej tradycji chrześcijaństwa, red. M. Manikowski, Wrocław 1998, s. 99.

${ }^{31}$ Por. S. del Cura Elena, Perikhóresis, w: Diccionario Teológico. El Dios cristiano, red. X. Pikaza, N. Silanes, Salamanca 1992, s. 1092.

${ }^{32}$ Por. tamże, s. 1094. 
społecznościach. W procesie nieustannego stwarzania ludzie są podnoszeni do wyższego sposobu bytowania nie oddzielnie, lecz wraz z innymi, z ,sąsiednimi elementami" 33 . Od strony doczesności aspekt personalny creatio continua ujawnia się w postaci rozróżniania i jednoczenia, prowadząc ku pełnej „komunalizacji” wszelkich stworzeń. Proces ten jest odwzorowaniem życia trzech różnych Osób Bożych, które są jednym Bogiem. Stwarzanie nowego człowieka wymaga z jego strony współpracy, (wpół)tworzenia, ponieważ człowiek został stworzony na obraz Boga trynitarnego i zaproszony do uczestniczenia w procesie „trynitaryzacji siebie, innych ludzi i całego Wszechświata ${ }^{34}$. Najlepszym odwzorowaniem życia Trójcy Świętej w świecie, najlepszym miejscem ciagłego stwarzania jest rodzina, która stanowi rodzaj „osoby zbiorowej” czy „społecznej”35.

\section{Chrystus centralnym źródłem creatio continua}

Próby zrozumienia Trójcy chrześcijańskiej w ramach filozofii i połączenia Jej działania z działaniem ludzkości, podjęte w XIX wieku przez przedstawicieli nurtu idealizmu: Hegla i Schellinga, doprowadziły do utworzenia systemów stricte filozoficznych, w których wykorzystano tylko triadyczne schematy, ale bez chrześcijańskiej treści. Hegel wymieszał Boga ze światem. Schelling przeciwnie, radykalnie oddzielił Boga od świata, przekreślając możliwość wcielenia Syna Bożego $^{36}$. W systemie Schellinga obok wątku filozoficznego można zauważyć wątek teologiczny. Skonstruował on model trynitologiczny dla wyjaśnienia exsystencji Boga, czyli wychodzenia Boga subsystującego w sobie poza siebie. W ten sposób uniknął panteizmu, w który wpadł jego adwersarz - Hegel. Myślicielom chrześcijańskim Schelling zarzucał zdradę, ponieważ mówili oni o Bogu przeważnie w sposób ogólny, bez podkreślania trynitarnośćc ${ }^{37}$. Tak oto człowiek, który nazywał siebie filozofem, był bardziej trynitologiczny od teologów, czyli bardziej od nich chrześcijański. Podejmował on refleksję nad wnętrzem Boga, nad Trójcą immanentną. Próbował utworzyć opis wiecznej wewnątrzboskiej teogonii, w której zawiera się otwartość na akt stworzenia świata ${ }^{38}$.

Próba trynitarnego ujęcia relacji Boga ze światem nie powiodła się. Był bardziej chrześcijański od Hegla, ale popadł w herezję nestorianizmu. Refleksja o Trójjedynym Stwórcy nie została zwieńczona z refleksją nad wcieleniem. W pró-

${ }^{33}$ Por. G. Greshake, Trójjedyny Bóg..., s. 244; zob. tenże, Wenn Leid mein Leben lähmt. Leiden - Preis der Liebe?, Freiburg i. Br. 1992, 11-64.

${ }^{34}$ Tamże, s. 245.

${ }^{35}$ C.S. Bartnik, Dogmatyka..., s. 318.

${ }^{36}$ Por. F. Tomatis, Schelling: mysterium Trinitatis, w: La Trinità e il pensare. Figuri percorsi prospettive, red. P. Coda; A. Tapken, Roma 1997, s. 45.

${ }^{37}$ Por. tamże, s. 48.

${ }^{38}$ Por. tamże, s. 59. 
bach rozważania zagadnienia creatio continua zabrakło mocnego punktu - stworzenia i przyjęcia natury ludzkiej przez Syna Bożego. Wskutek tego całość zagadnienia pozostała mglista, niewyraźna, nieprzekonywująca. Schelling był świadomy, że problem ciągłego stwarzania można opisać tylko w wierze trynitarnej. Dał temu wyraz w formule: Deus-Trinitas sive creatio continua ${ }^{39}$, ale nie potrafił nic powiedzieć o nowym, chrześcijańskim sposobie ciągłego stwarzania, które dokonuje się w Chrystusie, we wcielonym Synu Bożym.

Teologia chrześcijańska tworzy kreatologię w kontekście trynitologii oraz chrystologii, podkreślając tajemnicę wcielenia. Zamysł Boży tkwi w odwiecznym ruchu perychorezy Osób Bożych. Fundamentalnymi arteriami tego ruchu są dwa przechodzenia (processiones; procesje): rodzenie Syna przez Ojca oraz wychodzenie Ducha z wnętrza Ojca do swego wnętrza. Działania te, wraz z działaniem Ojca, który rodzi Syna i tchnie Ducha, są miejscem aktu stwórczego. Trynitarne wewnątrzboskie życie wyznacza strukturę aktu stwórczego i kształt oraz jego skutek. Kontynuacją aktu stwórczego jest objawienie splecione z działaniem zbawczym. W dziele objawienia centralne miejsce zajmuje wydarzenie wcielenia Syna Bożego, który w specyficzny dla siebie sposób jest odwiecznym wzorcem i źródłem creatio continua. Zbawcza misja Syna Bożego rozpoczyna się od aktu stworzenia świata, dokonuje się w dziejach świata i kończy w wydarzeniu paruzji. W niej odzwierciedla się wewnętrzne życie Boga, czyli Trójca immanent$\mathrm{na}^{40}$. Boskie processio odzwierciedla się $\mathrm{w}$ dziejach świata i zostanie dopełnione w paruzji. Dynamizm stworzeń będzie w pełni (na swoją miarę) zespolony z dynamizmem życia Boga.

Aspekt dziejowy, czyli działanie Chrystusa w świecie, łączy się z aspektem ontologicznym, w którym Jezus Chrystus jest Zasadą świata i odwiecznym Źródłem jego nieustannego rozwoju. Jest On uosobieniem ciagłego stwarzania, jest Stworzycielem działającym nieustannie - Creator continuum. Chrystus nie tylko stwarza (Christus Creator), lecz również zachowuje świat w istnieniu i rządzi nim

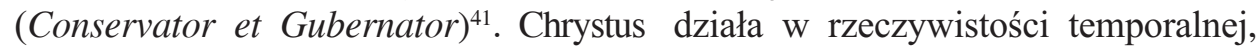
dysponując boską mocą stwarzania. Dokonuje się w Nim stworzenie świata i ludzi, a także przechodzenie osób ludzkich do sytuacji pełni. Oznacza to, że creatio continua jest tożsama z chrystyfikacją i diwinizacją ludzi, a za ich pośrednictwem, również świata materialnego ${ }^{42}$. Personalizacja ludzi złączona jest z personalizacją czasu, przestrzeni, materii. Czas zmienia swoją jakość, staje się coraz bardziej spersonalizowany, aż dojdzie do pełni, mocą Chrystusa, w Chrystusie ${ }^{43}$.

${ }^{39}$ Por. F. Tomatis, Schelling..., s. 61.

${ }^{40}$ Por. J.I. Saranyana, C.J. Alejos Grau, La teología trinitaria de Fray Jerónimo Oré, O.F.M. (1554-1630) en su «Symbolo Catholico Indiano», w: Actas del VII simposio de teología histórica (28-30 abril 1992), Valencia 1993, s. 223.

${ }^{41}$ Zob. C.S. Bartnik, Dogmatyka..., s. 290.

${ }^{42}$ Por. tenże, Historia i myśl, Lublin 1995, s. 82.

${ }^{43}$ Por. P. Liszka, Wptyw nauki o czasie..., s. 20. 
Podmiotem creatio continua jest też Duch Święty. Plan stworzenia i odkupienia, który należy do wewnętrznego życia Przenajświętszej Trójcy, jest dokonany odwiecznie przez Ojca i przez Syna w Duchu Świętym. Ojciec jest stwarzającym początkiem stworzenia, Syn kształtującym początkiem, a Duch początkiem udzielającym życia. Stworzenie istnieje w Duchu, uformowane jest przez Syna, a pochodzi od Ojca ${ }^{44}$.

\title{
Podsumowanie
}

Akt stwórczy od strony Boga jest jeden, ale ma kształt trynitarny, gdyż jest zawarty w wewnętrznym życiu Boga. Akt stwórczy to działanie Osób Bożych. Jego skutkiem jest świat, byty stworzone, nieożywione i ożywione, materialne i duchowe. Od strony dziejów świata akt stwórczy może być widziany jako czyn Boga, dzięki któremu dochodzi do zaistnienia świata, ale też w sensie ciagłego działania, podtrzymującego świat w istnieniu i powodującego ciagłe pojawianie się nowych bytów.

Stworzenie w sensie ogólnym, a w tym creatio continua, ma kształt trynitarny. Jest dziełem trzech Osób Boskich, a zwłaszcza dziełem Syna Bożego, który jako jedyny $\mathrm{z}$ Trzech ma w swojej specyfice personalnej możność przyjęcia natury ludzkiej. Możność ta została zaktualizowana w wydarzeniu wcielenia. Będąc Bogiem i człowiekiem, Chrystus jest nie tylko podmiotem działającym, lecz uosobionym Stwarzaniem.

\section{Trinitarian Aspect of Creatio Continua}

\begin{abstract}
The act of creation on the part of God is unique, but it has a trinitarian shape, since it is contained in the internal life of God. The act of creation is the action of Divine Persons. It culminated in the world, created living and non-living, material and non-material beings. From the perspective of world history the act of creation may be looked upon as an act of God that brought about the existence of the world and also as God's ongoing effort aimed at sustaining the world in its existence and constant bringing about new beings. Creation in general, including creatio continua, has a trinitarian shape. It is an act of three Divine Persons, and especially an act of the Son of God, who as the only one of the Trinity, has the ability to embrace our human condition. This ability found its reflection in the Incarnation. Being both God and man, Christ is not only an acting subject but also a personified Coming into existence.
\end{abstract}

${ }^{44}$ Zob. M. Kowalczyk, Opatrzność Boża w ujęciu personalistycznym, „Communio” 6(2002) 117-129, s. 118; Por. J. Moltmann, Bóg w stworzeniu, thum. Z. Danielewicz, Kraków 1995, s. 184; por. H.U. von Balthasar, Trójca Święta a stworzenie, w: Kosmos i człowiek, red. L. Balter, K. Czulak, P. Góralczyk, „Kolekcja communio” 4, Poznań-Warszawa 1989, s. 25. 


\section{Keywords}

act of creation, Providence, God, Trinity, creatio continua, persistence, development, fullness

\section{Słowa kluczowe}

akt stwórczy, opatrzność, Bóg, Trójca Święta, creatio continua, trwanie, rozwój, pełnia

\section{Bibliografia}

Balthasar H.U. von, Trójca Święta a stworzenie, w: Kosmos i człowiek, red. L. Balter, K. Czulak, P.P. Góralczyk, „Kolekcja communio” 4, Poznań-Warszawa 1989.

Bartnik C.S., Dogmatyka katolicka, t. 1, Redakcja Wydawnictw KUL, Lublin 2000.

Bartnik C.S., Historia i myśl, Lublin 1995.

Benz A., Skąd się pojawia coś nowego w Universum?, „Communio”, Stworzenie czy natura? 2(2002), s. 3-13.

Boulnois O., Nasza koncepcja Boga i Opatrzności, „Communio” 6(2002), s. 78-103.

Costa M.L., Emmanuel Lévinas y Hayyim de Volozhyn: praximidad e inspiración, „Anámnesis” (Meksyk) 1 (1998), s. 129-145.

Cristiani M., “Aeterni pia providentia Regis” - Opatrzność a rozumienie świata: Pomiędzy filozofia a chrześcijaństwem, „Communio” 6(2002), s. 3-17.

Cura Elena S. del, Perikhóresis, w: Diccionario Teológico. El Dios cristiano, red. X. Pikaza, N. Silanes, Salamanca 1992, s. 1086-1094.

Greshake G., Trójjedyny Bóg. Teologia trynitarna, tłum. J. Tyrawa, (Der Dreieine Gott. Eine trinitarische Theologie, Verlag Herder, Freiburg im Breisgau 2007³; 19971]), TUM, Wrocław 2009.

Greshake G., Wenn Leid mein Leben lähmt. Leiden - Preis der Liebe?, Freiburg i. Br. 1992, s. 11- 64.

Gunton C., Daleki odbłysk Evangelium. Zbawienie we Władcy Pierścieni Tolkiena, w: Tolkien. Księga pamiatkowa. Studia o spuściźnie literackiej, red. J. Pearce, (Tolkien: A celebration, HarperCollinsPublishers 1999), tłum. J. Kokot, Zysk i S-ka, Poznań 2003, s. 119-132.

Korczyński M., Teologia kosmiczna w pismach Pseudo Dionizego Areopagity, Radom 1997.

Kowalczyk M., Opatrzność Boża w ujęciu personalistycznym, „Communio” 6(2002), s. 117-129.

Kuksiewicz Z., Zarys filozofii średniowiecznej. Filozofia bizantyjska, krajów zakaukaskich, stowiańska, arabska i żydowska, PWN, Warszawa $1982^{2}$.

Liszka P., Wpływ nauki o czasie na refleksję teologiczna, Palabra, Warszawa 1992.

Łosski W. Teologia Mistyczna Kościoła Wschodniego, Warszawa 1989, s. 85-86.

Moltmann J., Bóg w stworzeniu, tłum. Z. Danielewicz, Kraków 1995.

Nawara P., Ksztaltowanie się koncepcji przebóstwienia ( $\theta \varepsilon \omega \sigma \iota \varsigma)$ w myśli teologiczno-filozoficznej wczesnego chrześcijaństwa, w: Studia z filozoficznej tradycji chrześcijaństwa, 
red. M. Manikowski, Filozofia XXVIII, Wydawnictwo Uniwersytetu Wrocławskiego, Wrocław 1998, s. 87-110.

Peacocke A.R., Creation and the World of Science, Oxford 1979.

Saranyana J.I., Alejos Grau C.J., La teología trinitaria de Fray Jerónimo Oré, O.F.M. (1554-1630) en su «Symbolo Catholico Indiano», w: Actas del VII simposio de teología histórica (28-30 abril 1992), Valencia 1993, s. 213-226.

Stróżewski W., Problem panteizmu w De Divinis Nominibus Pseudo Dionizego Areopagity, ,Roczniki Filozoficzne” 5(1955-57), z. 3, s. 39-59.

Tomatis F., Schelling: mysterium Trinitatis, w: La Trinità e il pensare. Figuri percorsi prospettive, red. P. Coda; A. Tapken, Città Nuova, Roma 1997, 45-64, s. 45.

Tupikowski J., Relacje między Bogiem a światem w ujęciu św. Tomasza z Akwinu u A.N. Whiteheada, Lublin 1999, doktorat, maszynopis.

Turoldo D.M., Misterium czasu, tłum. B. Żurowska, Kraków 2000.

Zamboni S., Luce dell'essere, Dio della tenebra, Ermeneutica della luce nel «Corpus areopagiticum», "Ricerche Teologiche" 10(1999) 119-167, s. 135.

Zimoń H., Istota najwyższa, w: Encyklopedia katolicka, t. 7, red. S. Wielgus, TN KUL, Lublin 1997, kol. 540-541. 